\title{
EDITORIAL
}

\section{Supporting Science in Canada}

The NSIS celebrated its $150^{\text {th }}$ anniversary in 2012. In its optimism, the Society assumed that Canada will be looking forward to another 150 years of science - natural and social, basic and applied - serving Canadian society and humanity as a whole. With a series of special lectures, members of NSIS were able to reflect upon the contributions of the citizens of Nova Scotia and the Maritimes to this field of endeavor, some of which have been recorded in the pages of the PNSIS over the years.

Yet presently, some areas of science in Canada are facing very challenging times. The country is being governed nationally by a federal government that, at best, views science solely as a way to boost the natural resource industry and the economy, and at worst is seen by many citizens to be actively opposed to basic science and the acquisition of scientific (evidence-based) knowledge, unless it has immediate economic benefits. The latter view is supported by the very long list of recent cutbacks to environmental and living resource science and science capacity within the federal public service, starting in 2006 (Dupuis 2013, Nikiforuk 2013, Wells 2013). These include the closure of publically supported research laboratories and programs (e.g., the ELA or Experimental Lakes Area program), the unparalleled closure of government libraries and archives, the stance against climate change (in terms of national and international policy, and related science support), the unprecedented and highly embarrassing withdrawal from important international environmental conventions (Kyoto, Desertification), the elimination of important advisory groups (e.g., the National Roundtable on Environment and Economy) and positions (Office of the National Science Advisor), and the obvious dislike of evidence-based policy making (see Dupuis 2013, Hodson 2012, Wells 2013, www.eiui.ca, among many others). To its credit, the NSIS wrote a letter to the Prime Minister to express its concern about this state of affairs, and after many months received an unconvincing reply, to which it has replied (see NSIS website). Clearly, given these challenges, NSIS should continue to be a visible advocate for science in Canada, and join with regional groups such as "Save Our Science" 
in St. Andrews, NB, to collectively, constructively and persistently voice our opinions.

The current situation (circa Dec. 2013) raises many important questions. These include: Do the cutbacks of some critical areas of science represent the wishes of Canadians? Do we, as scientists, collectively need to make a major new argument in favor of science for the public good? Do the general public and their politicians understand the roles and values of science in a modern industrialized democracy? If not, why not? How do scientific societies such as the NSIS engage the public in discussions about the direction of and support for Canadian science? How can societies such as ours add to an appreciation of science, along with the outstanding efforts of people and programs such as Quirks and Quarks (Bob MacDonald, CBC), other CBC programs (BobFournier, science commentator,CBC Radio 1, Halifax), the Nature of Things (David Suzuki), and NOVA (PBS). At present, we seem to be living (some say sleep walking) at a scientific crossroad; parts of our scientific enterprise are changing significantly in favor of selected industry and technology driven imperatives. Note the recent shift in the focus and operation of the prestigious National Research Council in Canada; it was once the pinnacle of the country's basic science and technology, and now it has been reorganized (some say reduced) to focus on supporting industry-based research. Answers to the above questions, and others that NSIS members undoubtedly can think of, are of paramount importance to the role of science in Canada's future.

Science has been an underpinning of the Canadian nation since Confederation. Unfortunately, it has had very few national champions, with some exceptions - e.g., Sir Sanford Fleming, John Polanyi, Michael Smith, David Suzuki. We have a host of productive and renowned research universities. To date, Canada has had 12 Nobel prize winners in diverse scientific fields (chemistry, physics, medicine), and many other awards as well, such as the Stockholm Water Prize to David Schindler (University of Alberta), and honourifics such as the Order of Canada. Major contributions have been made to many modern science fields, including original breakthroughs from pharmacology (e.g. the discovery of insulin) to marine science (e.g., the trophic biomass model), and contributions to the needs of industry from oil to forestry to mining. As a very large country with a relatively small (35.1 million, 2013) and widely distributed population, we have done reasonably well and with caveats continue to do so, according to the most recent evalua- 
tions (Council of Canadian Academies 2012, Science, Technology and Innovation Council 2013).

The question is - will our scientific contributions continue? We can always do better, in many areas, if we had strong leadership and support from various levels of government, and from our leading scientific societies and academies. This raises another set of questions: How do we as a country set our science priorities and keep advancing? How do we combat the current major cutbacks in certain core areas of Canadian environmental science-aquatic sciences and toxicology (Hodson 2012, Wells 2013), climate change and Arctic research (e.g.closure of PEARL or the Polar Environment Atmospheric Research Laboratory, cessation of the Northern Research Chairs program, withdrawing funding from the Kluane Lake Research laboratory in the Yukon, amongst others). How do we retain or even regain our leadership position in many fields with our science oriented neighbours to the south (i.e., the USA) and in Europe? How do we produce a science literate and empathetic population, with an interest in discovery and creativity? How do we vigorously promote the STEM topics (science, technology, engineering, mathematics) in our school systems? How do we emphasize the various rewards that careers in science bring? There are many questions and challenges, all urgent to the economy and overall health of our nation, its citizens, and its natural landscapes, ecosystems and wildlife. But we are capable of finding appropriate answers and opportunities to lead us back on the right road.

As a modern, resource-based nation, we need a balance between support for the basic sciences and support for the applied and industry directed sciences. The latter should strive for objectivity and not become mired in controversy, e.g., witness the current case in Nova Scotia with a university accepting an industry funded grant in coastal aquaculture. We also need to support small, one or two-investigator driven programs as well as large, elite, multi-investigator ones; the former has proven many times to lead to fundamental discoveries. New discoveries of a fundamental nature form the bedrock of eventual applied use, mostly not seen at the time, e.g., lasers, which are now ubiquitous, are used from grocery stores to ophthalmology; describing the structure of DNA revolutionized molecular biology and led to dynamic new fields such as genomics. Most of these discoveries are the work of inspired and energetic single investigators, not teams, though this does not apply to all fields (e.g., astronomy and space exploration) and may change in 
the future. We cannot easily predict where and when the next major breakthroughs will occur. For example, it is believed that we are entering the phase of the third life sciences revolution, with "the convergence of the life sciences with the physical sciences and engineering, the first two revolutions being the discovery of DNA and genomics (Kastner 2009). What will be discovered can only be imagined, and much will be completely unexpected and serendipitous. To facilitate basic discoveries and then to move them to the stages of technology and innovation, we need a science literate politic in Canada.

To be fair, the federal government in Canada in recent years has been supporting large programs and centres of excellence in specific topics, under its Canada Foundation for Innovation (CFI) granting process. This has led to many large programs, from understanding the human-computer interface to establishing the healthy oceans network. Recently, the government has announced investing in a new research station in Cambridge Bay, Nunuvat for science and technology research; critics say its location is too far south, and not as good an investment as at smaller more northerly sites. The current government likes big "flashy" pronouncements and studies that suggest instant applications to industrial applications, and has been reducing funding for smaller grant applications and facility support through the Canadian research councils (NSERC, SSHRC, CHRC). Though perhaps well intended, this benefits the few, not the majority of researchers. As well, the government has been eliminating many areas of public service research, especially in the environmental sciences, e.g., its marine ecotoxicology, climate change and polar science programs.

Two recent examples of how Canada is faring with its scientific enterprise should be mentioned again. These are described in 2013 reports of the Science, Technology and Innovation Council (an advisory council to the Government of Canada) and the Council of Canadian Academies (STIC 2013; CCA 2012). While we aspire to global leadership, there are "vitally important areas where our performance is lagging, where we must improve - in some cases significantly" (STIC 2013). Importantly, it was pointed out that "Canada's gross domestic expenditures on R\&D (GERD) declined from their peak in 2008 ...... and Canada's rank in 2011 is $23^{\text {rd }}$ of 41 economies" (STIC 2013). The CCA report is a critical read - while putting a shiny face on what the country excels in, "half of the S\&T experts surveyed considered Canada to have lost ground in the past five years" and described a 
decline in natural resources and environmental S\&T (CCA 2012). NSIS members are encouraged to read these reports and make their own judgement as to how well we are doing in Canadian science and technology as a whole, and specific scientific fields important to the future of the Atlantic region.

On the value of science as a whole enterprise, there are general insightful comments in a recent book by Edward Wilson of Harvard University (Wilson 2013), regarding science and the future, and the classics of Peter Medawar (Medawar 1980) Carl Sagan (Sagan 1990) and Freeman Dyson (Dyson 2006) are worth revisiting in this context as history tends to repeat itself. Importantly, there is a need to continue to interest young people in all aspects of science, something that NSIS has long recognized and attends to annually through its writing program.

In conclusion, we need to support basic science in the region, utilize the information and knowledge that we already have, and encourage evidence-based public policy and decision-making on a lot of issues. The NSIS can continue to foster discussion of the many issues pertaining to the role of science in NS and the Maritimes, and in the larger Canadian fabric. The Society can encourage the young to pursue their dreams in areas of scientific and personal discovery. And it can defend Canadian science when it is unwittingly attacked and diminished. NSIS has many critical roles here, including holding workshops or round tables to discuss these issues. It is hoped that its members will ponder this editorial, offer their views, write letters to their MPs on issues vitally important to this region and the country, and continue to support the Society's programs.

\section{LITERATURE CITED}

Council of Canadian Academies. (2012). The State of Science and Technology in Canada, 2012. CCA website.

Dupuis, J. (2013). Confessions of a science librarian. The Canadian war on science: a long, unexaggerated, devastating chronological indictment. Science Blogs, May 20, 2013.

Dyson, F. (2006). The Scientist as Rebel. NYREV, Inc., New York, NY. 361p.

Hodson, P. (2012). A vitally important issue. SETAC (Society for Environmental Toxicology and Chemistry). Globe, Vol. 13(6), June 21, 2012. 
Kastner, M. (2009). The science we need and the needs of science. MIT Faculty Newsletter XXI, No. 5, Summer 2009.

Medawar, P. (1980). The Threat and the Glory: Reflections on Science and Scientists. Harper Collins.

Nikiforuk,A. (2013). What's driving chaotic dismantling of Canada's science libraries? The Tyee, 23 Dec, 2013. TheThyee.ca (accessed Jan. $\left.2^{\text {nd }}, 2014\right)$.

Sagan, C. (1990). Why we need to understand science. Skeptical Inquirer 14(3), Spring 1990.

Science, Technology and Innovation Council. (2013). State of the Nation 2012 - Canada's Science, Technology and Innovation System: Aspiring to Global Leadership. (PDF, 6.30MB, 120p). Released, May 2013.

Wells, P.G. (2013). Editorial. Canadian aquatic science and environmental legislation under threat. Mar. Pollut. Bull. 69(2013):1-2.

Wilson, E. (2013). Letters to a Young Scientist. Liveright Publ. Corp., W.W. Norton and Co., New York, London.

Peter G. Wells

Editor, PNSIS

December 2013 